\title{
Effects of Iron and Amloki (Emblica Officinalis) on Serum Zinc Level in Anaemia with Pregnancy
}

\author{
Tahmina Akter ${ }^{* 1}$, Qazi Shamima Akther ${ }^{2}$, Saima Haque Lisa ${ }^{3}$, \\ Mst. Ariza Sultana ${ }^{4}$, Sunjida Akter Suma ${ }^{5}$, Rahnuma Ahamad ${ }^{6}$
}

\begin{abstract}
Introduction: Pregnancy is associated with several trace elements deficiency in developing countries. Supplementation of iron in iron deficiency anaemia (IDA) has several side effects including alterations of serum zinc level. Traditionally, amloki is used as a well known supplement in pregnancy, which is rich in trace elements. Aims were to determine the effects of iron and amloki on serum zinc level in IDA with pregnancy. Materials and Methods: This Prospective, longitudinal and interventional study was done by non blinded, non randomized sampling followed by inclusion and exclusion criteria. This study was performed in the Department of Physiology, Dhaka Medical College, Dhaka on 43 pregnant women between 13th to 20th weeks of gestation with IDA from July 2016 to June 2017. They were recruited from Outpatient Department of Obstetrics and Gynaecology of Dhaka Medical College Hospital. Anaemic pregnant women supplemented with oral iron and amloki were considered as study group (A) and control group $(B)$ were with only iron supplementation for 45 days. Serum zinc level was estimated in the laboratory of the Department of Soil, Water and Environment, University of Dhaka, Dhaka. For statistical analysis, Paired Student's ' $t$ ' test and Unpaired Student's 't' test were considered using SPSS 22.0 version. Results: Significant decrease $(p<0.001)$ of serum zinc level was observed after intervention of iron in both groups. In this study, there was no significant difference in serum zinc level in between study and control group. Conclusion: It can be concluded that oral iron supplementation causes decrease in serum zinc level in IDA with pregnancy. Amloki shows no significant role in preventing decrease of serum zinc level in this study.
\end{abstract}

Keywords: Iron deficiency anaemia, Pregnancy, Amloki, Zinc.

Number of Table: 01; Number of Figure: 01; Number of References: 21; Number of Correspondence: 05.

*1. Corresponding Author:

Dr. Tahmina Akter, M.Phil (Physiology)

Lecturer

Department of Physiology

Dhaka Medical College and Hospital, Dhaka.

Email: tahmina.runa.akter1@gmail.com

2. Dr. Qazi Shamima Akther, M.Phil

Professor and Head

Department of Physiology

Dhaka Medical College and Hospital, Dhaka.

3. Dr. Saima Haque Lisa, M.Phil

Assistant Professor

Department of Physiology

Parkview Medical College and Hospital, Sylhet.

4. Dr. Mst. Ariza Sultana, M.Phil

Assistant Professor

Department of Physiology

National Institute of Neurosciences and Hospital, Dhaka.

5. Dr. Sunjida Akter Suma, M.Phil.

Lecturer

Department of Physiology

Dhaka Medical College and Hospital, Dhaka.

6. Dr. Rahnuma Ahamad, M.Phil.

Assistant Professor

Department of Physiology

Medical College for Women and Hospital, Dhaka.

\section{Introduction:}

Qualitative or quantitative deficiency of haemoglobin or red blood cells in circulation is called anaemia which leads to decreased oxygen carrying ability of blood to organ and tissues ${ }^{1}$. Iron deficiency anaemia (IDA) is the most common type and considered for one-half of anaemia cases. Low iron stores in the body causes decreased red blood cell production ${ }^{2,3}$.

In organisms after iron, zinc is the second most important transitional metal. Zinc is the only metal presents in all enzyme classes and required for catalytic activity of many enzymes. For normal growth and development of pregnancy, childhood and adolescence zinc is essential. Even at low concentration it is an effective antimicrobial agent. For proper sense of taste and smell zinc is required. Dietary zinc is absorbed from the duodenum to blood through $\mathrm{DMT}^{1}$. In blood, zinc is transported by albumin (60\%) and transferrin $(10 \%)$. Zinc is excreted through feces, skin and saliva ${ }^{4,5}$.

Pregnancy with IDA is usually associated with decreased serum zinc level. Serum zinc reduces due to increased demand and haemodilution in pregnancy, and also for formation of zinc-protoporphyrin due to deficiency of iron ${ }^{6,7}$. There are some interactions between iron and zinc during absorption and transport in the blood. The divalent metal transporter1 (DMT1) is the common transporter for both ferrous iron and zinc in the proximal small intestine from lumen to the enterocyte ${ }^{8}$. So, dietary intake of iron can influence the absorption of zinc. Different iron preparations are used to treat IDA in pregnancy which can lead to zinc deficiency 9 .

Indian mythology believes amloki as the first tree to be created in the 
universe. It is a medium sized tree. Leaves are small, oblong, narrow and pinnately arranged. Fruits are globose $1 / 2-1$ inch in diameter with central depression, fleshy and 6-lobed, with 6 small seeds. The tree is $30-40 \mathrm{ft}$ in height and circumference of stem usually extends up to 3-6 ft and rarely up to $9 \mathrm{ft}$. Stem is usually curved, branches are strong and extended. Bark is thin and brownish in colour. Leaves resemble to tamarind leaves. Raw fruits are green in colour and become greenish yellow on ripening. Tree is known as Phyllanthus emblica, Emblica officinalis (latin name) from the Family: Euphorbiaceae ${ }^{10,11,12}$.

In India, so many researches have done on Emblica officinalis as an important ingredient of different ayurvedic preparation to cure IDA in pregnancy. Most of these researches have proved that Amloki has the efficacy to increase haemoglobin level and improves iron status during pregnancy ${ }^{13,14}$.

Amloki is renowned for its nutritional elements, which is rich in polyphenols, minerals $(0.7 \%)$, considered as one of the richest source of vitamin $\mathrm{C} 11,12$. Many researchers have found presence of significant amount of zinc and other trace elements in amloki ${ }^{15,16}$. So, The study was undertaken to observe the effect of iron and amloki supplementation on serum zinc level in iron deficient pregnant women.

\section{Materials and Methods:}

On 43 pregnant women with IDA, this prospective interventional study was done. This study conformed to the Helsinki Declaration and was approved by the concerned departments, Research Review committee and Ethical Review Committee of Dhaka Medical College, Dhaka. After, fulfilling all the ethical aspects this study was performed in the department of Physiology of Dhaka Medical College. Subjects were in between 18 to 36 years having gestational age of 13 th to 20 th weeks. They were recruited from the outpatient department of Obstetrics and Gynaecology of DMCH, Dhaka on the basis of inclusion and exclusion criteria. Subjects were explained about the nature, purpose and benefit of the study in details. They were counselled for voluntary participation and allowed to withdraw from the study whenever they feel like. Informed written consent was taken from the participants. All the informations were recorded in a prefixed questionnaire. A detailed of pregnant females including socio economic condition, food habit, parity, menstrual history were taken along with haematological examination. They were free from any known cardiac, renal, liver and endocrine disorders. Compliance to the supplementation was monitored by regular telephonic communications. Amloki capsules and iron tablets were given in boxes for 45 days and participants were encouraged to continue the supplied medicine daily. Serum zinc level was estimated in the laboratory of the Department of Soil, Water and Environment, University of Dhaka, Dhaka. This parameter was studied 2 times in all subjects of control and study groups, i.e. at the beginning of the study (baseline) and after 45 days of study period. Diet and physical activity of the patients remained unchanged during the course of study. Clinically diagnosed and confirmed ( $\mathrm{Hb} 8$ to $<11 \mathrm{gm} / \mathrm{dl}$ ) patients of iron deficiency anaemia were selected and divided into two groups, 25 pregnant women with IDA, were supplemented with oral amloki capsules (1.072 gm) thrice daily and iron tablet [ferrous fumarate $(200 \mathrm{mg})+$ folic acid $(0.02 \mathrm{mg})]$ once daily for 45 days, were considered as study group (Group A). Again, 21 pregnant women with IDA, supplemented with only iron tablet once daily for 45 days were considered as control group (Group B). One subject discontinued the study due to reluctance in group A after two weeks, while 2 subjects from control group left Dhaka after 4 weeks of study. So, finally 24 subjects of study and 19 subjects of control groups completed the study.

The amloki capsule (Amlahills) was authentified by the Department of Pharmaceutical Chemistry, Faculty of Pharmacy, University of Dhaka, which was manufactured by Isha Agro Developers PVT.LTD, India.

Paired Student's ' $t$ ' test and Unpaired Student's ' $t$ ' test were performed using SPSS Version 22.0 for statistical analysis. Mean $\pm \mathrm{SD}$ were used for data expression. The $\mathrm{p}$ value $<0.05$ was taken as level of significance.

\section{Results:}

The results are shown in table I and Figure 1. In this study, the mean serum zinc level was almost similar in A1 and B1 groups, and no statistically significant differences were observed. In group A2, the serum zinc $(p<0.001)$ level was found significantly decreased in comparison to that of A1. Again, in group B2, the serum zinc $(p<0.001)$ level was found significantly decreased in comparison to that of B1. While, in group A2, decreases in serum zinc $(p=0.286)$ was not statistically significant in comparison to that of B2.

Table -I: Serum zinc level in respective groups $(n=43)$.

\begin{tabular}{lcccc}
\hline \multirow{2}{*}{ Parameter } & \multicolumn{4}{c}{ Groups } \\
\cline { 2 - 5 } & $\mathrm{A}_{1}(24)$ & $\mathrm{A}_{2}(24)$ & $\mathrm{B}_{1}(19)$ & $\mathrm{B}_{2}(19)$ \\
\hline Zinc $(\mu \mathrm{g} / \mathrm{dl})$ & $57.18 \pm 12.03$ & $54.28 \pm 11.08$ & $53.30 \pm 16.17$ & $50.09 \pm 14.30$ \\
& & & & \\
Statistical analysis & \multicolumn{4}{c}{$p$ value } \\
\hline Parameter & $\mathrm{A}_{1}$ vs A $_{2}$ & $\mathrm{~A}_{1}$ vs B B & $\mathrm{B}_{1}$ vs B & $\mathrm{A}_{2}$ vs B \\
\hline Zinc & $<0.001$ & 0.372 & $<0.001$ & 0.286 \\
\hline
\end{tabular}

Results are shown as mean \pm SD. Paired t- test was considered for comparison within groups and unpaired ttest to compare between groups. The significance of the tests were calculated $\&$ p value $<0.05$ was considered as level of significance.

$\mathrm{N}=$ Total number of subjects, $\mathrm{n}=$ number of subjects in each group;

A1: Study group (At baseline)

A2: Study group (After intervention with Amloki and iron tablet) 
B1: Control group (At baseline)

B2: Control group (After intervention with iron tablet)

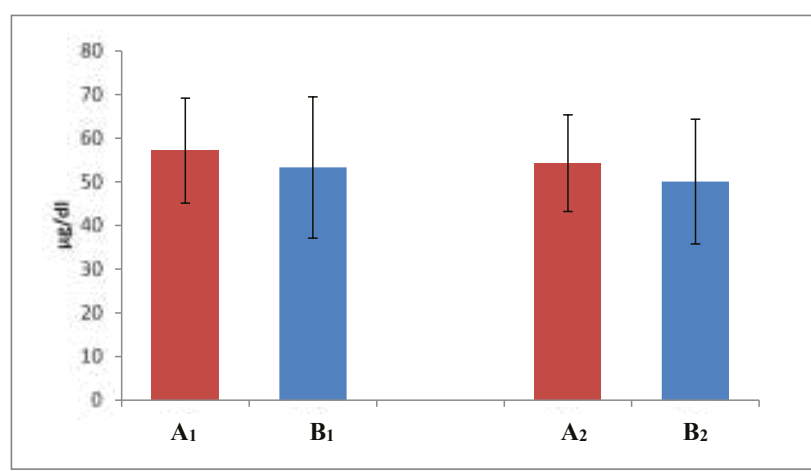

Figure-1: Mean serum zinc level in different groups $(n=43)$.

$\mathrm{N}=$ Total number of subjects

A1: Study group (At baseline)

A2: Study group (After intervention with amloki and iron tablet)

B1: Control group (At baseline)

B2: Control group (After intervention with iron tablet)

\section{Discussion:}

In this study, the decrease in serum zinc $(p=0.286)$ level was not statistically significant in amloki and iron supplemented group in comparison to that of only iron supplemented group. But decrease in serum zinc level $(p<0.001)$ was found statistically significant in both groups in comparison to their baseline value.

O'Brien et al. (1999) also found no significant difference in serum zinc level in between (iron + zinc) supplemented group and only iron supplemented group 9 . They found significant decrease in serum zinc level in iron supplemented group in comparison to without iron supplemented group. Different researchers also found that, supplementation of iron during pregnancy causes decreased zinc absorption ${ }^{17,18}$.

In pregnancy, serum zinc level decreases due to increased demand and hemodilution. Normally, iron bind with protoporphyrin IX to form haem. But, in case of iron deficiency, zinc replaces iron and combines with protoporphyrin IX. This combination further decreases serum zinc level in pregnant women with iron deficiency anaemia $^{19,6,20}$.

Some researchers suggested that, supplementation of iron can inhibit the absorption of zinc. Divalent metal transporter 1 (DMT1) in the duodenal enterocyte, is the common transporter for iron and zinc. These three elements compete to bind with the same transporter. When iron is supplemented, there is increased iron concentration at the site of absorption. Increased concentration of iron causes competitive displacement of zinc and copper from DMT1. Again, exposure to supplemental iron leads to down regulation of DMT1. That will subsequently decrease zinc absorption ${ }^{21,7}$. In this study, no significant differences were observed in serum zinc level in between amloki with iron supplemented group and only iron supplemented group, after 45 days of supplementation. Though amloki contain significant amount of zinc, it could not prevent the decrease of serum zinc level in iron deficient pregnant women. The cause may be due to improper iron and zinc ratio, as iron-zinc ratio $>2: 1$ can impair zinc absorption. Again, supplementation of iron during pregnancy may decrease zinc absorption ${ }^{9}$.

Though, the actual mechanisms responsible for decreased serum zinc by oral amloki supplementation cannot be explained from the present experiment as the phytochemical study of amloki powder was not done.

\section{Conclusion:}

The results concluded that oral iron intervention for the treatment of IDA in pregnancy causes decreased serum zinc level. In this study, Amloki shows no significant effect on serum zinc level.

\section{Conflict of Interest: None.}

\section{Acknowledgement:}

The authors acknowledge Department of Pharmaceutical Chemistry, Faculty of Pharmacy and Department of Soil, Water and Environment, University of Dhaka for their kind cooperation.

\section{References:}

1. Roy A, Dwivedi M. Dhatrilauha: right choice for iron deficiency anemia in pregnancy. Ayu. 2014; 35(3):283-288. DOI: 10.4103/0974-8520.153745

2. Short MW, Domagalski JE. Iron deficiency anemia: evaluation and management. Am Fam Physician. 2013; 87(2):98-104.

URL: https://www.aafp.org/afp/2013/0115/afp20130115 p98.pdf

3. Layeeq S, Thakar AB. Clinical efficacy of amloki rasayana in the management of pandu (iron deficiency anemia). Ayu. 2015; 36(3): 290-297.

DOI: $10.4103 / 0974-8520.182761$

4. Ugwuja EI, Ejikeme BN, Ugwu NC, Obido O. A comparative study of plasma trace elements (copper, iron and zinc) status in anaemic and non-anaemic pregnant women in Abakaliki, Nigeria. Online $\mathbf{J}$ of Health Allied Sci. 2011; 10(2):1-3

URL: http://www.ojhas.org/issue38/2011-2-10.htm

5. Osredkar J, Suster N. Copper and zinc, biological role and significance of copper/ zinc imbalance. J Clinic Toxicol. 2011; S3(001): 1-18.

DOI: $10.4172 / 2161-0495 . S 3-001$ 
6. Upadhyaya C, Mishra S, Ajmera P, Sharma P. Serum iron, copper and zinc status in maternal and cord blood. Indian J of clinical Bio Chem. 2004; 19(2): 48-52. doi: 10.1007/BF02894257

7. Arredondo M, Martinez R, Nunez MT, Ruz M, Olivers M. Inhibition of iron and copper uptake by iron, copper and zinc. Biol Res. 2006; 39:95-102.

http://dx.doi.org/10.4067/S0716-97602006000100011

8. Nelson JC, Westwood M, Allen KR, Newton KE, Barth $\mathrm{JH}$. The ratio of erythrocyte zinc-protophyrin to protophyrin IX in disease and its significance in the mechanism of lead toxicity on haem synthesis. Ann Clin Biochem. 1994; 35: 422-426. DOI: $10.1177 / 000456329803500313$

9. O'Brien KO, Zavaleta N, Caulfield LE, Yang DX, Abrams SA. Influence of prenatal iron and zinc supplements on supplemental iron absorption, red blood cell iron incorporation, and iron status in pregnant Peruvian women. Am J Clin Nutr. 1998; 69: 509-15.

https://doi.org/10.1093/ajcn/69.3.509

10. Govind P, Pandey SP. Phytochemical and toxicity study of Emblica officinalis (Amla). Int Res J Pharmacy. 2011; 2(3): 270-272.

https://www.researchgate.net/publication/270214450_Phyt ochemical_and_toxicity_study_of_Emblica_officinalis_A mla

11. Yadav V, Duvey B, Sharma S, Devi B. Amla (Emblica officinalis)- medicinal food and pharmacological activity. Int J Pharm Chem Sci. 2014; 3(3): 616-619. file://C:/Users/user/AppData/Local/Temp/7846065.pdf

12. Jain R, Pandey R, Mahant RN, Rathore DS. A review on medicinal importance of Emblica officinalis. Int $\mathbf{J}$ Pharm Sci Res. 2015; 6(1): 73-84.

https://ijpsr.com/bft-article/a-review-on-medicinal-importa nce-of-emblica-officinalis/?view=fulltext

13. Khot BM, Patil AJ, Kakad AC. Comparative clinical study of dhatri lauha and navayasa lauha in garbhini panduroga with reference to anemia in pregnancy.
Int Org Sci Res J Dental Med Sci. 2013; 11(1): 28-33. https://www.iosrjournals.org/iosr-jdms/papers/Vol11-issue 1/F01112833.pdf?id=8158

14. Ramadevi G, Jonah S, Prasad UN. A clinical study on the effect of dhatri lauha in garbhinipandu (iron deficiency anaemia). Int. J. Res. Ayurveda Pharm. 2014; 5(6): 708-712.

http://dx.doi.org/10.7897/2277-

15. Singh NKS, Devi CB, Singh TS, Singh NR. Trace elements of some selected medicinal plant of Manipur. Indian J Nat Prod Resour. 2009; 1(2): 227-231.

http://nopr.niscair.res.in/bitstream/123456789/9831/1/IJN PR\%201\%282\%29\%20227-231.pdf

16. Kumar VN, Vibha, Ashwani K. A comparative study of heavy metals in Emblica officinalis, Phyllanthus emblica and Azadirachta indica. Int Res J Biological Sci. 2013; 2(8):16-19.

http://www.isca.in/IJBS/Archive/v2/i8/4.ISCA-IRJBS-201 3-075.pdf

17. Hambidge KM, Krebs NF, Jacobs MA, Favier A, Guyette L, Ikle DN. Zinc nutritional status during pregnancy: a longitudinal study. Am J Clin Nutr. 1983; 37: 429-442. DOI: 10.1093/ajcn/37.3.429

18. Fung EB, Ritchie LD, Woodhouse R, Roehl R, King JC. Zinc absorption in women during pregnancy and lactation: a longitudinal study. Am J Clin Nutr. 1997; 66:80-88. DOI: 10.1093/ajcn/66.1.80

19. Hastka J, Lasserre JJ, Schwarzbeeck A, Hehlmann. Central role of zinc protopophyrin in staging iron deficiency. Clin Chem. 1994; 40(5):768-773.

https://pubmed.ncbi.nlm.nih.gov/8174250/

20. Ozhan O, Erdem N, Aydogdu I, Arkurt A, Kuku I. Serum zinc levels in iron deficient women: a case-control study. Turk J Hematol. 2016; 33: 156-158.

DOI: $10.4274 /$ tjh. 2015.0206

21. Arredondo M, Munoz P, Mura CV, Nunez MT. DMT1, a physiologically relevant apical $\mathrm{Cu} 1+$ transporter of intestinal cells. Am J Physiol. 2003; 284(C):1525-1530. DOI: 10.1152/ajpcell.00480.2002 